\title{
Effect of the Tryptophan Hydroxylase Inhibitor Telotristat on Growth and Serotonin Secretion in 2D and 3D Cultured Pancreatic Neuroendocrine Tumor Cells
}

\author{
Aura D. Herrera-Martínez ${ }^{a}$ b Richard A. Feelders $^{a}$ Rosanna Van den Dungen ${ }^{a}$ \\ Fadime Dogan-Oruc ${ }^{a}$ Peter M. van Koetsveld ${ }^{a}$ Justo P. Castaño ${ }^{b}$ Wouter W. de Herder ${ }^{a}$ \\ Leo J. Hofland ${ }^{a}$ \\ a Division of Endocrinology, Department of Internal Medicine, Erasmus MC, University Medical Center Rotterdam, \\ Rotterdam, The Netherlands; ${ }^{b}$ Maimonides Institute for Biomedical Research of Cordoba (IMIBIC), Córdoba, Spain
}

\section{Keywords}

Telotristat · In vitro effect · Neuroendocrine tumors .

Serotonin secretion · Growth

\begin{abstract}
Serotonin, a biologically active amine, is related to carcinoid syndrome in functioning neuroendocrine tumors (NETs). Telotristat ethyl is a novel inhibitor of the tryptophan hydroxylase (TPH), a key enzyme in the production of serotonin. While its use in patients with carcinoid syndrome and uncontrolled diarrhea under somatostatin analogs (SSAs) has been recently approved, in vitro data evaluating its effectiveness are lacking. For this reason, we aimed to evaluate the effect of telotristat as monotherapy, and in combination with SSAs, on proliferation and secretion in a NET cell line model. The human pancreatic NET cell lines BON-1/QGP-1 were used as $2 \mathrm{D}$ and $3 \mathrm{D}$ cultured models; somatostatin receptor and TPH mRNA expression, as well as the potential autocrine effect of serotonin on tumor cell proliferation using a 3D culture system were evaluated. Telotristat decreased serotonin production in a dose-dependent manner at a clinically feasible concentration, without affecting cell proliferation. Its combination with pasireotide, but not with octreotide, had an additive inhibitory effect on serotonin se-
\end{abstract}

karger@karger.com

(c) 2019 S. Karger AG, Basel

www.karger.com/nen

Karger! cretion. The effect of telotristat was slightly less potent, when BON-1 cells were co-treated with octreotide. Octreotide and pasireotide had no effect on the expression of TPH. Telotristat did not have an effect on mRNA expression of somatostatin receptor subtypes. Finally, we showed that serotonin did not have an autocrine effect on NET cell proliferation on the 3D cell model. These results suggest that telotristat is an effective drug for serotonin inhibition, but the effectiveness of its combination with $\mathrm{SST}_{2}$ (somatostatin receptor subtype 2)-preferring SSA should be evaluated in more detail.

(c) 2019 S. Karger AG, Basel

\section{Introduction}

Neuroendocrine tumors (NETs) are slow-growing neoplasms derived from neoplastic proliferation of enterochromaffin cells, which are able to synthesize, store, and secrete different types of biologically active amines and peptides, including serotonin $[1,2]$. Serotonin is synthesized from the essential amino acid l-tryptophan. Tryptophan hydroxylase (TPH) converts tryptophan to 5 -hydroxytryptophan, which is subsequently converted to serotonin [3]. Usually, serotonin, produced by a midgut 
NET, is metabolized by the liver and does not cause systemic symptoms, but when liver metastases are present, many patients present with systemic features of the carcinoid syndrome, including flushing (94\%), diarrhea (78\%), abdominal pain $(51 \%)$, and cardiac valvular complications (53\%), which can lead to heart failure $[4,5]$. Carcinoid syndrome is usually related to metastasized midgut NETs, but it may also be observed in patients with bronchial or ovary carcinoids, even if liver metastasis is absent [6]. Systemic levels of serotonin can be measured by tracking the excretion of urinary serotonin metabolite 5-hydroxyindoleacetic acid (u5-HIAA). When elevated u5HIAA excretion is observed, the tumor is usually widely spread and associated with severe carcinoid syndrome and on the long-term carcinoid heart disease $[7,8]$.

Somatostatin analogs (SSAs), targeting somatostatin receptor (SST) subtype 2, are recognized as the standard of care for patients with carcinoid syndrome as SSAs inhibit serotonin secretion by NETs $[9,10]$. Long-acting preparations of SSAs are especially used, since they improve flushes in $53-75 \%$ and diarrhea in $45-80 \%$ of cases [9]. Despite the effectiveness of SSAs, loss of response during prolonged treatment has been reported. Tachyphylaxis, downregulation of cell surface SSTs, development of antibodies to SSAs, as well as SSTs gene mutations have been hypothesized [11, 12].

Telotristat ethyl is a novel TPH inhibitor. This drug acts peripherally due to its elevated molecular weight and acidic moieties, which prevent it from crossing the bloodbrain barrier, thus avoiding the inhibition of TPH in the central nervous system $[8,13,14]$. Its metabolite, the hippurate salt of telotristat ethyl, reduced serotonin levels throughout the gastrointestinal tract in mice and improved clinical symptoms without several adverse effects [14]. Additionally, international, multicenter, blind, clinical studies have reported significant reduction in the frequency of bowel movements and urinary u5-HIAA excretion in patients with carcinoid syndrome not adequately controlled by SSAs $[8,14,15]$. Telotristat ethyl has recently been approved by the US Food and the Drug Administration and the European Medicine Agency for the treatment of diarrhea in those patients with carcinoid syndrome who are inadequately controlled by SSAs. Telotristat is also considered as a category $2 \mathrm{~A}$ recommendation in the National Comprehensive Cancer Network clinical practice guidelines [16-18]. Despite the promising results reported in clinical trials, surprisingly very litthe information on the in vitro effects of the drug is available in the literature. In this context, we aimed to evaluate the in vitro effect of telotristat as monotherapy, as well as in combination with SSAs, on proliferation and secretion in cell line models of NET. To the best of our knowledge, this study extensively describes for the first time the direct effects of telotristat in two-dimensional (2D) and threedimensional (3D) cell culture models of NETs.

\section{Materials and Methods}

\section{Cell Cultures}

The human pancreatic NET cell lines BON-1 and QGP-1 were used. The BON-1 cell line (kind gift of Dr. Townsend from the University of Texas Medical Branch, Galveston, TX, USA) was derived from a lymph node metastasis of a human functioning PNET. The cell line QGP-1 was established from a somatostatin-secreting pancreatic islet cell carcinoma and purchased from the Japanese Collection of Research Bioresources Cell Bank (JRCB, Osaka, Japan) [19].

BON-1 cells were cultured in D-MEM/F12 (GIBCO Biocult Europe, Breda, The Netherlands) containing 10\% fetal calf serum (FCS), L-glutamine, fungizone $(0.5 \mathrm{mg} / \mathrm{L})$ and penicillin $10^{5} \mathrm{U} / \mathrm{L}$ (Bristol-Myers Squibb, Woerden, The Netherlands). QGP-1 cells were cultured in RPMI 1640 (GIBCO Biocult Europe) containing $10 \%$ FCS and penicillin $10^{5} \mathrm{U} / \mathrm{L}$ (Bristol-Myers Squibb). Cell lines were cultured in $75 \mathrm{~cm}^{2}$ flasks (Greiner bio-one, The Netherlands) at $37^{\circ} \mathrm{C}$ in a $5 \% \mathrm{CO}_{2}$ incubator. Cells were harvested with trypsin $(0.05 \%)$-EDTA $(0.53 \mathrm{~mm})$ and resuspended in culture medium. Cell viability always exceeded $87 \%$. For the serotonin assays, cells were cultured in medium containing $0.1 \%$ bovine serum albumin (BSA), after an initial incubation of $24 \mathrm{~h}$ in medium with $10 \%$ FCS to allow cell attachment.

Pancreatic NETs may produce carcinoid syndrome due to the secretion of serotonin and tachykinins [20-22]; the serotonin secretion of BON-1 and QGP-1 cell lines has been reported in several articles, and their neuroendocrine phenotype has recently been confirmed [23-25]. For these reasons, a PNET model was chosen for this research.

\section{$2 D$ Cultures (Monolayer)}

Cells were plated in 24-well plates with $1 \mathrm{~mL}$ medium at the density necessary to obtain a $65-70 \%$ cell confluence in the control groups at the end of the experiment (50,000 cells/well for BON-1 and 30,000 cells/well for QGP-1; data not shown). Drug treatment was started after $24 \mathrm{~h}$ of incubation. In those experiments performed in $0.1 \%$ BSA, a higher number of cells was used $(85,000$ cells/well for BON-1 and 100,000 cells/well for QGP-1). Cells were incubated during 3 days with the indicated drugs. Prolonged periods of incubation in serum-deprived monolayer cultures resulted in a significant loss of cell viability.

\section{$3 D$ Cultures (Spheroids)}

Non-scaffold-based 3D cell cultures were used. Cells (750 cells/ well for BON-1 and 1,500 cells/well for QGP-1) were plated in cell repellent-coated 24-well plates (cellstar ${ }^{\circledR}$; Greiner Bio-One B.V., Alphen aan den Rijn, The Netherlands). After $72 \mathrm{~h}$ of initial incubation in $1 \mathrm{~mL}$ medium with $10 \%$ FCS, spheroids were washed twice with medium containing $0.1 \%$ BSA. Medium was refreshed and drugs were added. Spheroids were incubated during 7 days with the indicated drugs, and medium and drugs were refreshed on day 3. 


\section{Drugs and Reagents}

The active metabolite of telotristat ethyl (LP-778902, herein named as telotristat) was purchased from Bio-Connect B.V. (The Netherlands). All the experiments described in this article were performed with the active compound LP-778902, and its use is referred in the results as telotristat. LP-778902 was evaluated since it is the systemically available active compound in humans. Pasireotide (PAS) and octreotide (OCT) were obtained from Novartis Pharma (Basel, Switzerland). Telotristat was dissolved in dimethyl sulfoxide (DMSO). The evaluated concentrations of telotristat (LP-778902: $10^{-5}$ to $10^{-12} \mathrm{M}$ ) were chosen on the basis of literature reports and included the clinically relevant plasma concentration $\left(10^{-8} \mathrm{M}\right)$, which is based on the active moiety of the drug [14]. Vehicle (DMSO 0.4\% final concentration) was added into the control wells. The calculated half maximal inhibitory concentration $\left(\mathrm{IC}_{50}\right)$ for both cells lines was used for the combination experiments with SSAs. The $\mathrm{IC}_{50}$ and the maximal evaluated concentration were used for evaluating the autocrine effect of serotonin on cell proliferation in the 3D model with spheroids. PAS and OCT were dissolved in medium until obtaining the final concentrations tested, $10^{-8}$ to $10^{-9} \mathrm{M}$, corresponding to the clinically relevant concentrations according to the literature [26-28]. PAS and OCT were chosen based on their different SSTs affinity (OCT and lanreotide bind preferably to $\mathrm{SST}_{2}$, and PAS has high binding affinity to multiple SSTs, particularly $\mathrm{SST}_{5}$ ) [29].

\section{Measurement of Total DNA Content}

After the incubation period, cells and spheroids were harvested for DNA measurement, as a measure of cell number. The procedure for the total DNA measurement has been previously described in detail $[30,31]$. Briefly, cell pellet was treated with $150 \mu \mathrm{L}$ of ammonia solution ( $1 \mathrm{~mol} / \mathrm{L})$ - Triton X 100 (0.2\% v/v). After 15 min, sonification was performed (Soniprep 150; amplitude 1,400 $\mu \mathrm{m})$. Thereafter, in $2 \mathrm{D}$ cultures, $1 \mathrm{~mL}$ assay buffer $(100 \mathrm{mM} \mathrm{NaCl}$, $100 \mathrm{~mm}$ EDTA, $10 \mathrm{~mm}$ Tris; $\mathrm{pH}$ 7.0) was added, and $20 \mu \mathrm{L}$ of the solution was mixed with $200 \mu \mathrm{L}$ of Hoechst dye H33258 solution $(1 \mu \mathrm{g} / \mathrm{mL})$; fluorescence was measured with the excitation and emission wavelengths set at 350-455 nM and referenced to a standard curve of calf thymus DNA (type II, no D-3636; Sigma-Aldrich, Zwijndrecht, The Netherlands). In 3D cultures (spheroids), the Quant-iT ${ }^{\mathrm{TM}}$ PicoGreen ${ }^{\mathrm{TM}}$ dsDNA assay kit (Thermo Fisher Scientific, The Netherlands) was used, fluorescence was measured with the excitation and emission wavelengths set at 485-535 nM and referenced to the standard curve of the kit. This assay (as almost all the other available DNA content assays) is an indirect measure of DNA content. Its use was chosen based on its high accuracy in fresh, homogeneous samples. Additionally, the absence of washing procedures (as in trypan blue assays) decreases the possibility of harvesting cells during the incubation period. Finally, no methods for the appropriate discrimination of all types of dead cells (including flow cytometric) are available, for these reasons [32].

\section{Methylthiazolyldiphenyl-Tetrazolium Bromide Assay}

Proliferation was confirmed by the methylthiazolyldiphenyltetrazolium bromide (MTT) assay (Sigma-Aldrich). Briefly, 3,000 cells/well were plated in 96-well plates, and on the day of measurement, $100 \mu \mathrm{L}$ of MTT diluted in d-PBS (Sigma-Aldrich) were added to the cells and then incubated for $3 \mathrm{~h}$ at $37^{\circ} \mathrm{C}$. Subsequently, cells were detached with lysis buffer ( $10 \%$ SDS, $0.56 \%$ glacial acetic acid in DMSO) and absorbance measured using the FlexStation system plate reader, at $570 \mathrm{~nm}$. In all instances, cells were plated per quadruplicate, and all assays were repeated twice.

\section{Quantitative RT-PCR}

The mRNA expression of SSTs ( $\left.\mathrm{SST}_{1}, \mathrm{SST}_{2}, \mathrm{SST}_{3}, \mathrm{SST}_{5}\right)$ in monolayer and spheroids in both cell lines was evaluated by quantitative RT-PCR. We used a previously described method [33]. In short, poly $\left(\mathrm{A}^{+}\right)$mRNA was isolated using Dynabeads Oligo (deoxythymidine $)_{25}$ (Dynal AS, Oslo, Norway). The poly $\left(\mathrm{A}^{+}\right)$mRNA was eluted in $\mathrm{H}_{2} \mathrm{O}\left(65^{\circ} \mathrm{C}\right)$ twice for 2 min each and used for $\mathrm{cDNA}$ synthesis in a Tris buffer ( $50 \mathrm{~mm}$ Tris- $\mathrm{HCl}$ [pH 8.3], $100 \mathrm{~mm} \mathrm{KCl}$, $4 \mathrm{~mm}$ dithiothreitol, and $10 \mathrm{~mm} \mathrm{MgCl}_{2}$ ) with $10 \mathrm{U}$ ribonuclease inhibitor, $2 \mathrm{U}$ avian myeloblastosis virus super reverse transcriptase, and $1 \mathrm{~mm}$ of each deoxynucleotide triphosphate in a final volume of $40 \mu \mathrm{L}$. This mixture was incubated for $1 \mathrm{~h}$ at $42^{\circ} \mathrm{C}$, and the resulting cDNA was diluted 5-fold in $160 \mu \mathrm{L}$ sterile $\mathrm{H}_{2} \mathrm{O}$. The total reaction volume $(25 \mu \mathrm{L})$ consisted of $10 \mu \mathrm{L} c \mathrm{cNA}$ and $15 \mu \mathrm{L}$ TaqMan Universal PCR Mastermix (Applied Biosystems, Branchburg, NJ, USA). Primers were used at a final concentration of $300 \mathrm{~nm}$ and probe at $200 \mathrm{~nm}$. Real-time qPCR was performed in 96-well optical plates with the TaqMan Gold nuclease assay (Applied Biosystems, Roche) and the ABI Prism 7700 Sequence Detection System (PerkinElmer, Foster City, CA, USA). After two initial heating steps at $50^{\circ} \mathrm{C}(2 \mathrm{~min})$ and $95^{\circ} \mathrm{C}(10 \mathrm{~min})$, samples were subjected to 40 cycles of denaturation at $95^{\circ} \mathrm{C}(15 \mathrm{~s})$ and annealing at $60^{\circ} \mathrm{C}(60 \mathrm{~s})$. All samples were assayed in duplicate. Values were normalized against the expression of the housekeeping gene HPRT. Dilution curves were constructed to calculate PCR efficiencies (E) for every primer-probe set [34]. To exclude genomic DNA contamination in the RNA, the cDNA reactions were also performed without reverse transcriptase and amplified with each primer pair. To exclude contamination of the PCR mixtures, the reactions were also performed in the absence of cDNA template. The sequence of used SSTs primers and efficiencies are described in online supplementary Table 1 (see www.karger.com/doi/10.1159/000502200 for all online suppl. material, ). Tryptophan hydroxylase-1 (TPH-1) PCR primers (Sigma Aldrich) were designed using the Universal Probe Library of Roche (https://www.roche-applied-science.com) based on the reported mRNA sequences in the National Center for Biotechnology Information database (NCBI, Bethesda, MD, USA). The primers and their sequences are forward TGAGACACAGTTCAGATCCCTTC and reverse GCGGGACATGACCTAAGAT. For each PCR, a mastermix was prepared on ice, containing per sample: $2 \mu \mathrm{L}$ cDNA, $5 \mu \mathrm{L}$ of $2 \times$ SensiFAST ${ }^{\mathrm{TM}}$ SYBR Green Reaction Mix (Bioline Inc., Taunton, MA, USA), and $0.4 \mu \mathrm{M}$ of both reverse and forward primers. The PCRs were run on a QuantStudio 7 Flex real time PCR system thermocycler (Applied Biosystems, Foster City, CA, USA). The relative expression of genes was calculated using the comparative threshold method, $2^{-\Delta \mathrm{C} 1}$ [35], after efficiency correction of target and reference gene transcripts (HPRT) [36].

\section{Serotonin Secretion Assay}

The medium of monolayer and spheroids cultures was collected from each well. Ascorbic acid $(0.1 \%)$ was added into all the samples that were used for the serotonin assay. The commercially available serotonin high sensitive ELISA (IBL international, Hamburg Germany) was used following the instructions of the manufacturer. Experiments were performed in quadruplicate and repeated twice. 
Fig. 1. Dose-dependent effect of telotristat on cell growth and serotonin secretion in monolayer PNET cells. a Effect of 3 days of treatment with telotristat on cell growth and serotonin secretion in BON-1 cells. b Effect of 3 days of treatment with telotristat on cell growth and serotonin secretion in QGP-1 cells. The interrupted line represents cell amount, the continuous line represents serotonin secretion. The gray vertical dashed line represents the clinically relevant plasma telotristat concentration. Values represent mean \pm SEM and are shown as a percentage of untreated control cell amount (DNA content per well) or serotonin concentration in the culture medium. The mean of serotonin absolute values in BON-1 controls was $1,562 \pm 130.7 \mathrm{pg} / \mathrm{mL}$ and in QGP-1 cells $84.96 \pm 7.9 \mathrm{pg} / \mathrm{mL}$.

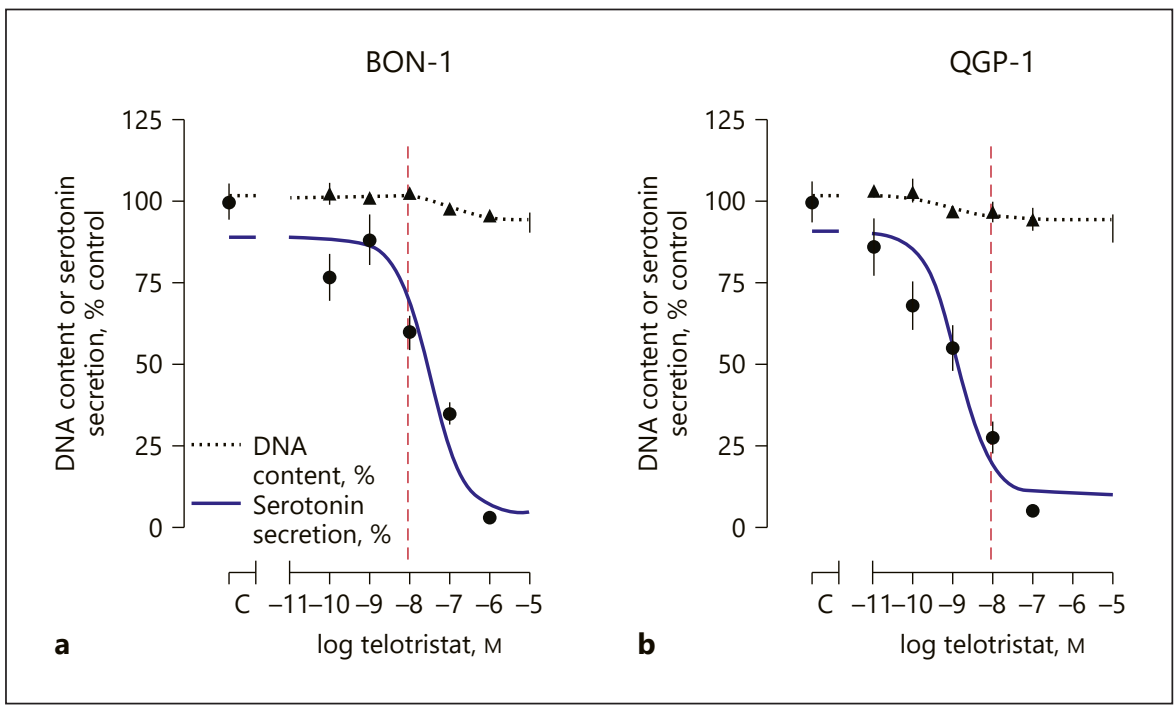

\section{Western Blotting}

To assess changes in the protein expression of $\mathrm{SST}_{2}$ and TPH-1, cells were washed and lysed in SDS-DTT buffer after $72 \mathrm{~h}$ of treatment incubation. Proteins were separated by SDS-PAGE and transferred to nitrocellulose membranes (EMD Millipore, Billerica, MA, USA). Membranes were blocked with 5\% non-fat dry milk in Tris-buffered saline with $0.05 \%$ Tween 20 and incubated overnight at $4{ }^{\circ} \mathrm{C}$ with primary antibodies (anti- $\beta$-tubulin: $2128 \mathrm{~S}$ [Cell Signaling, Danvers, MA, USA]; anti-TPH-1: ab30574 [Abcam, Cambridge, UK]). Secondary horseradish peroxidase-conjugated anti-rabbit were purchased from Cell Signaling (Danvers, MA, USA). Proteins were developed by using ECL detection system (GE Healthcare, UK) with dyed molecular weight markers. A densitometric analysis of the bands was carried out with Image J software (National Institutes of Health, Bethesda, MD, USA).

\section{Statistical Analysis}

For the statistical analysis, the statistical software of GraphPad Prism version 5 (GraphPhad Software, San Diego, CA, USA) was used. Between-group comparisons were made by the KruskalWallis test. Differences were considered to be statistically significant at $p<0.05$. Results are expressed as mean \pm SEM and percentages unless otherwise specified. log transformation was used for calculating the $\mathrm{IC}_{50}$.

\section{Results}

\section{Effects on Cell Proliferation and Serotonin Secretion}

Telotristat strongly decreased serotonin secretion in a dose-dependent manner in BON-1 (Fig. 1a) and QGP-1 cells (Fig. 1b) after 3 days of incubation. QGP-1 cells were more sensitive to telotristat $\left(\mathrm{IC}_{50}: 1.3 \times 10^{-9} \mathrm{M} ; 95 \% \mathrm{CI}\right.$ : $\left.7.3-2.4 \times 10^{-9} \mathrm{M}\right)$ than BON-1 cells $\left(\mathrm{IC}_{50}: 3.3 \times 10^{-8} \mathrm{M}\right.$; $\left.95 \% \mathrm{CI}: 1.8-6.2 \times 10^{-8} \mathrm{M}\right)$. The clinically relevant concentration of telotristat $\left(10^{-8} \mathrm{M}\right)$ decreased serotonin secre- tion by $40.1 \pm 17.4 \%$ in BON-1 and by $72.5 \pm 15.2 \%$ in QGP- 1 cells $(p<0.001)$. Serotonin release was totally suppressed in both cell lines after the incubation with the maximal evaluated dose $\left(10^{-5} \mathrm{M}\right)(p<0.001)$. No statistically significant effect on cell growth (DNA content per well) was observed in cells incubated with telotristat for 3 days in medium containing $0.1 \%$ BSA (Fig. 1) or 10\% FCS (online suppl. Fig. 1). Additionally, cell metabolic activity was evaluated using an MTT assay. No statistically significant effect on metabolic activity was observed in BON-1 or QGP-1 cells incubated with telotristat for 3 days in medium containing $0.1 \%$ BSA (online suppl. Fig. 2A, B, respectively) or 10\% FCS (online suppl. Fig. 2C, $D$ respectively).

The combination treatment with telotristat and SSAs (PAS and OCT) had no statistically significant effect on cell growth in both cell lines (Fig. 2). In BON-1 cells, OCT $10^{-8}$, but not $10^{-9} \mathrm{M}$, decreased serotonin secretion by $26.7 \pm 19.4 \%(p<0.05)$. Remarkably, the effectiveness of the combination treatment of telotristat and OCT on serotonin release was slightly lower than telotristat alone (telotristat: $55.1 \pm 13.1 \%, p<0.001$; telotristat + OCT $10^{-8} \mathrm{M}: 36.0 \pm 29.4 \%, p<0.01$; telotristat + OCT $10^{-9} \mathrm{M}$ : $30.6 \pm 25.5 \%, p<0.01$ ) in BON-1 cells (Fig. 2a). PAS $\left(10^{-8} \mathrm{M}\right)$ decreased serotonin secretion in BON-1 monolayer cultures more potently than OCT by $43.5 \pm 6.6 \%$, and its combination with telotristat had an additive effect (serotonin secretion reduction by $63.2 \pm 8.9 \%$; $p<$ $0.001)$ when compared to telotristat alone $(44.1 \pm 19.1$; $p<0.001$; Fig. 2b). PAS, at a concentration of $10^{-9} \mathrm{M}$, did not significantly reduce serotonin secretion in BON-1 cells. 


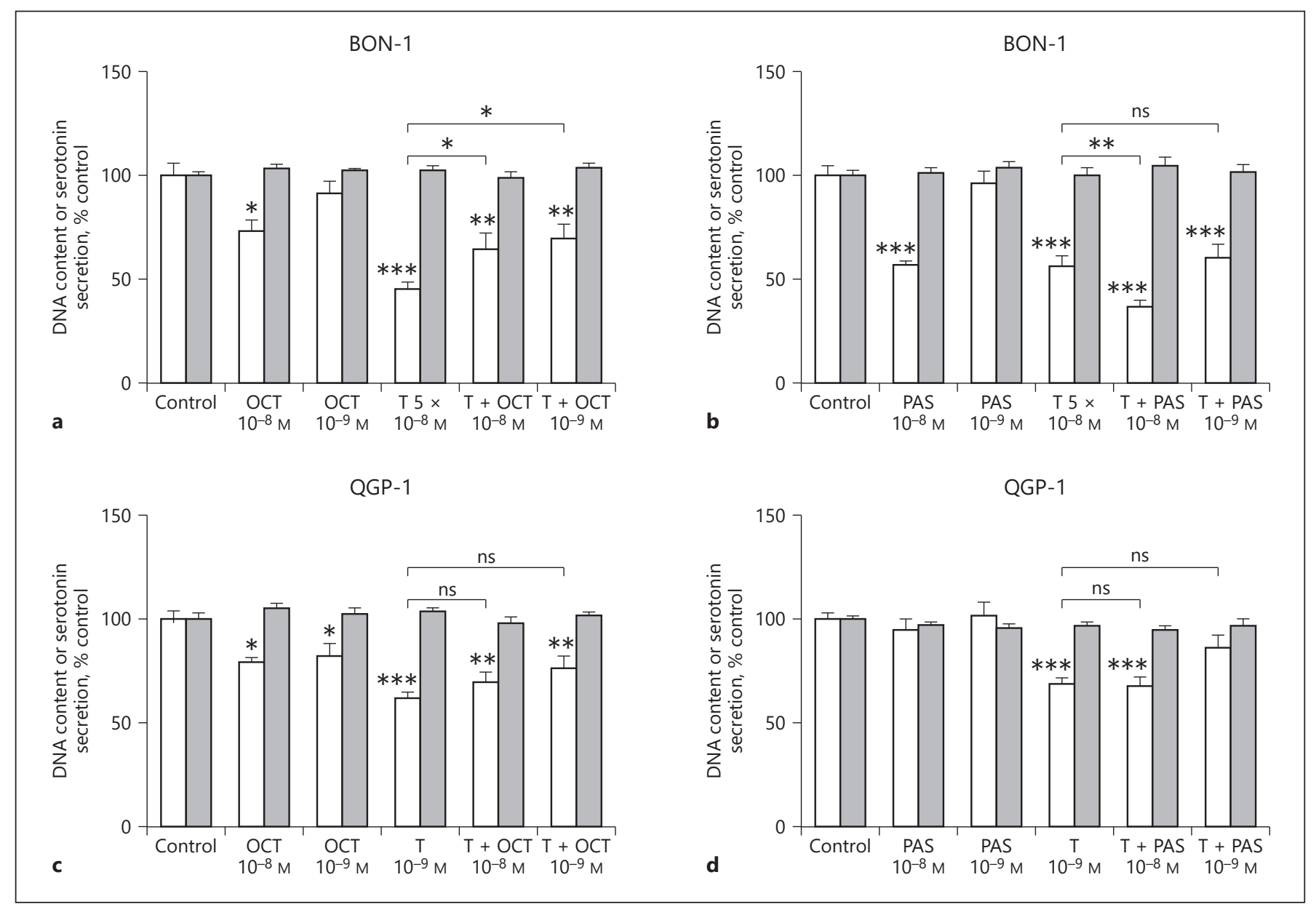

Fig. 2. Effect of the combination therapy with telotristat and somatostatin analogs on cell growth and serotonin secretion in monolayer PNET cells. a Combination treatment of telotristat (T) and octreotide (OCT) in BON-1 cells. b Combination treatment of T and pasireotide (PAS) in BON-1 cells. c Combination treatment $\mathrm{T}$ and OCT in QGP-1 cells. $\mathbf{d}$ Combination therapy of T and PAS in QGP-1 cells. Gray columns represent cell proliferation; white col-

In QGP- 1 cells, OCT $10^{-8} \mathrm{M}$ and $10^{-9} \mathrm{M}$ decreased serotonin secretion by $21.1 \pm 7.3 \%$ and $-17.9 \pm 21.0 \%$, respectively $(p<0.05)$. Combination treatment did not significantly alter the effect of telotristat alone (Fig. 2c). Serotonin secretion was not significantly affected by PAS (Fig. 2d).

\section{Effects of Telotristat on the Autocrine Effect of \\ Serotonin on Cell Proliferation in a 3D Spheroid \\ Culture System}

In order to evaluate the potential autocrine/paracrine in vitro effect of serotonin on cell proliferation in BON-1 and QGP-1 cells, a 3D spheroid culture system was used. umns represent serotonin secretion. For experiments on cell growth, DNA content per well was determined as a measure of cell number. Values represent mean \pm SEM and are shown as a percentage of untreated control. ${ }^{*} p<0.05$; ${ }^{* *} p<0.01$; ${ }^{* * *} p<0.001$, compared to untreated controls. The mean of serotonin absolute values in BON-1 controls was $836.9 \pm 67.3 \mathrm{pg} / \mathrm{mL}$ and in QGP-1 cells $285.9 \pm 25.4 \mathrm{pg} / \mathrm{mL}$.

The reduction in serotonin release induced by telotristat in BON-1 spheroids was similar to BON-1 monolayer cultures (Fig. 3a). QGP-1 spheroids were slightly less sensitive to telotristat than the monolayer cultures, but the maximal concentration tested still fully abolished serotonin secretion $\left(10^{-5} \mathrm{M} ; p<0.001\right.$; Fig. $\left.3 \mathrm{~b}\right)$. Despite the fact that serotonin secretion was totally suppressed after 7 days of incubation with the maximal tested telotristat dose in both cell lines, no significant changes in spheroid growth (DNA content) were observed in BON-1 (Fig. 3a) or QGP-1 3D cultures (Fig. 3b). Serotonin levels also did not have an effect on the morphology of the spheroids. Representative images after 7 days of incubation without 
Fig. 3. Effect of telotristat on cell growth and serotonin secretion in BON-1 and QGP-1 spheroids. a Effect of telotristat on cell growth (DNA content per well) and serotonin secretion in BON-1 spheroids. b Effects of telotristat on cell growth and serotonin secretion in QGP-1 spheroids. Representative images of BON-1 (c) and QGP-1 (d) spheroids after 7 days of incubation with increasing doses of telotristat (T). Gray columns represent cell proliferation; white columns represent serotonin secretion. Values represent mean \pm SEM and are shown as a percentage of control. *** $p<0.001$. The mean of serotonin absolute values in BON-1 control spheroids was $7,555 \pm 269.9 \mathrm{pg} / \mathrm{mL}$ and in QGP-1 cells $3,363 \pm 366.6 \mathrm{pg} / \mathrm{mL}$.

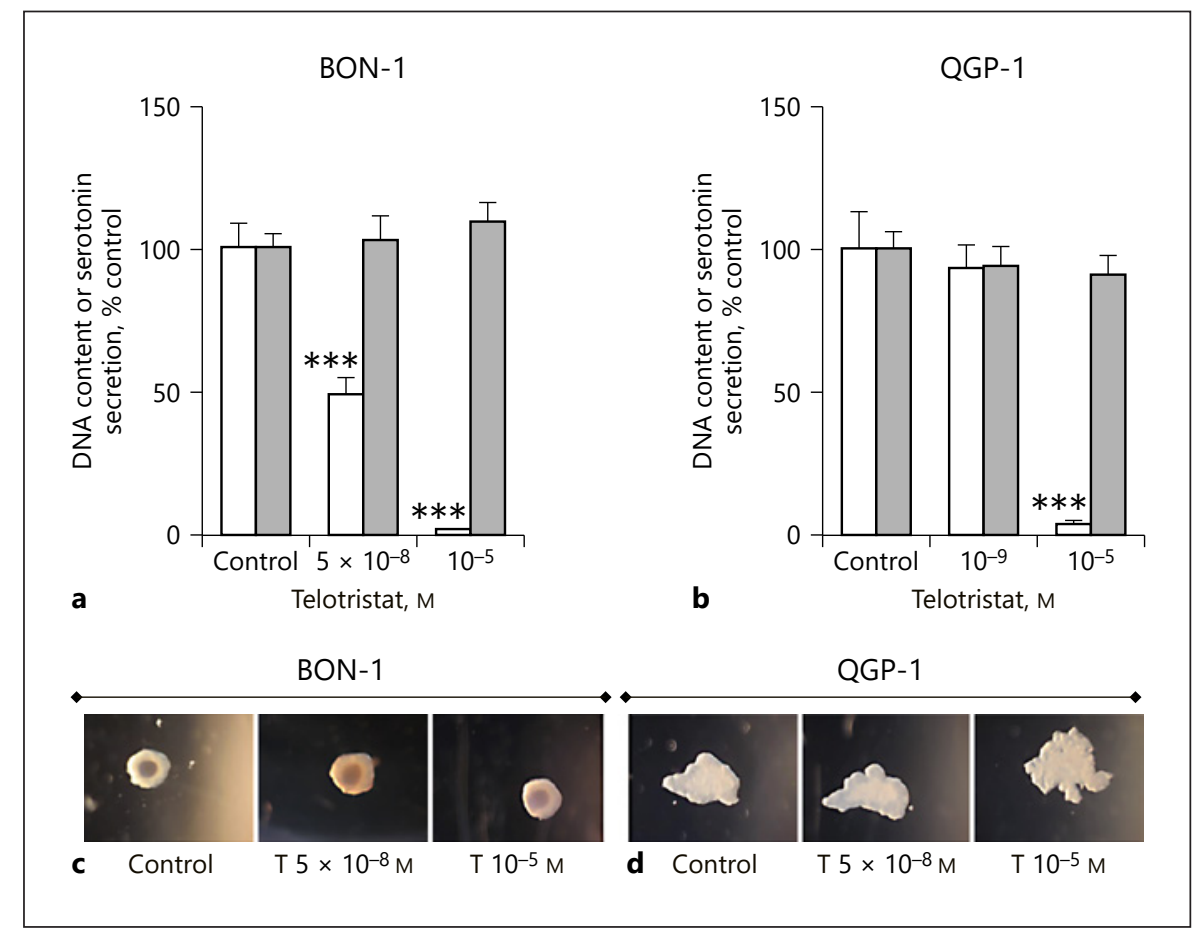

or with telotristat are depicted in Figures $3 \mathrm{c}$ (BON-1 spheroids) and d (QGP-1 spheroids).

\section{Effect of Telotristat on Somatostatin Receptor \\ Expression}

In order to rule out the possibility that telotristat influences SSTs expression, we evaluated the effect of telotristat on SSTs subtype expression. Figure 4 shows that telotristat $\left(5 \times 10^{-8} \mathrm{M}\right.$ for BON-1 and $10^{-9} \mathrm{M}$ for QGP- 1$)$ had no significant effect on the expression of SSTs in monolayer cultures of BON-1 and QGP-1 cell lines (Fig. 4a, b, respectively). Similar results were observed in $\mathrm{BON}-1$ and QGP-1 spheroids treated with telotristat (Fig. 5a, b, respectively).

\section{Effect of OCT and PAS on the Expression of TPH-1}

In order to explore a putative mechanism of action of telotristat and the interaction with SSAs, we evaluated the effect of OCT and PAS on TPH-1 mRNA and protein expression. Figure 6 shows that OCT $\left(10^{-8} \mathrm{M}\right)$ or PAS $\left(10^{-8}\right.$ M) did not have a statistically significant effect on the expression of TPH-1 in monolayer cultures of BON-1 and QGP-1 cell lines (Fig. 6a, b respectively). In addition, telotristat (telotristat $5 \times 10^{-8} \mathrm{M}$ for BON-1 and $10^{-9} \mathrm{M}$ for QGP-1), had no effect on TPH expression (Fig. 6a, b, right panels). To confirm these results, the expression of TPH-
1 was determined using Western blotting. OCT $\left(10^{-8} \mathrm{M}\right)$ or PAS $\left(10^{-8} \mathrm{M}\right)$ and telotristat (telotristat $5 \times 10^{-8} \mathrm{M}$ for BON-1 and $10^{-9} \mathrm{M}$ for QGP-1) did not have a statistically significant effect on the protein expression of TPH-1 in BON-1 or QGP-1 cells (Fig. 7a, b, respectively).

\section{Discussion}

The aim of this study was to evaluate the in vitro effects of telotristat and its combination with SSAs on growth and serotonin secretion in a model of pancreatic NET cells. Some publications and clinical trials have reported the clinical and biochemical effects of telotristat in combination with OCT in patients with carcinoid syndrome $[8,37,38]$. Recently, its use in patients with carcinoid syndrome and inadequately controlled diarrhea has been approved $[16,17]$. Despite the clinical application of telotristat, to the best of our knowledge only one published study has evaluated the effect of telotristat on synthesis of the serotonin precursor 5-hydroxytryptophan in a pancreatic NET cell line [39]. In the current study, we systematically evaluated the in vitro effects of telotristat on serotonin secretion and cell growth in mono- and combination therapy with SSAs in two different pancreatic NET cell lines using 2D and 3D cell culture models. 


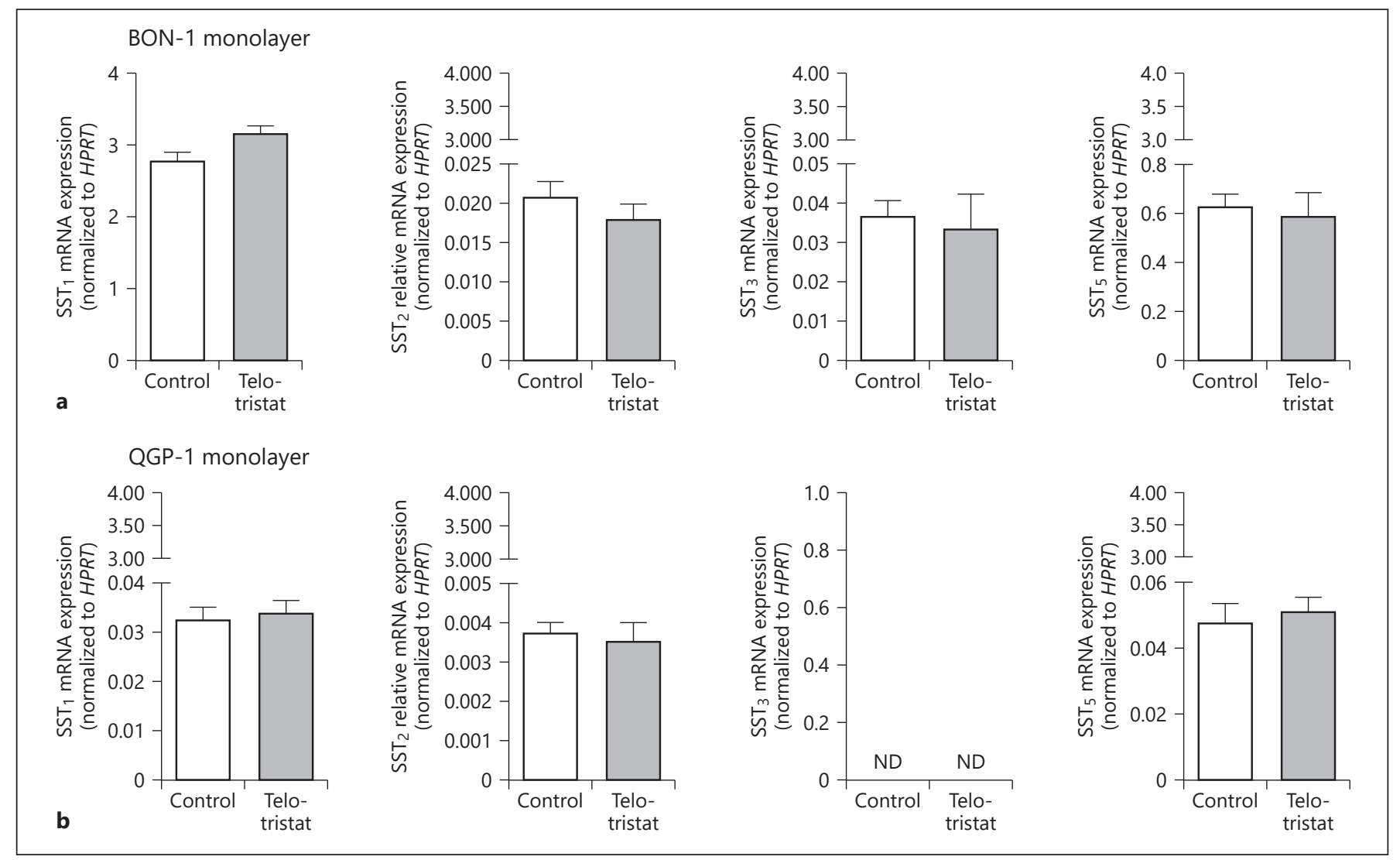

Fig. 4. Effect of telotristat on mRNA expression profile of somatostatin receptors in BON-1 and QGP-1 cell lines using monolayer culture systems. Relative mRNA expression normalized to HPRT in monolayer cultures of BON-1 (a) and QGP-1 (b) cell

Telotristat did not affect cell proliferation in either monolayer or spheroid cultures, even when very high doses were tested. Moreover, no effects on the morphology of 3D NET spheroids were observed. These results indicate that telotristat does not display any cytotoxicity, in concordance with clinical studies in which no serious adverse effects have been described. In addition, mild or moderate events were similar in patients treated with telotristat and in those treated with placebo $[8,15,37]$, suggesting the relative safety of use of telotristat in NET patients.

Telotristat strongly decreased serotonin secretion in a dose-dependent manner in both cell lines similar to clinical studies, in which the clinical and biochemical effects of telotristat were shown to be time- and dose-dependent $[8,15,38]$. Moreover, the concentration of telotristat that induced a $50 \%$ reduction of serotonin secretion by the NET cell lines $\left(1.3 \times 10^{-9}\right.$ to $\left.3.3 \times 10^{-8} \mathrm{M}\right)$ was in agreement with the clinically relevant concentrations of the lines. The mRNA expression of BON-1 and QGP-1 was not statistically significantly altered by telotristat at a concentration of $5 \times$ $10^{-8}$ and $10^{-9} \mathrm{M}$, respectively. Values represent mean \pm SEM. ND, non-detectable. drug, i.e. $10^{-8} \mathrm{M}[14]$. Similarly, preclinical studies have reported decreased intestinal serotonin content after using small-molecule TPH-1 inhibitors [40, 41], and clinical studies also reported statistically significant reduction from baseline u5-HIAA levels in patients with carcinoid syndrome who were already on a stable dose of SSAs $[8$, $15,38]$. Preclinical experimental models of intestinal inflammation have also reported some beneficial roles of TPH-1 inhibitors including reduced colon and jejunum serotonin content, reduced expression of proinflammatory genes, and reduced severity of chemical-induced colitis and enteric parasite-induced inflammation in mice [41]. Other beneficial effects of TPH-1 inhibitors include improvements in the mineral status, microarchitecture, and bone strength in animal models with chronic kidney disease [42].

Telotristat has been approved for the treatment of carcinoid syndrome (flushes and diarrhea) in combination with SSAs therapy in adults inadequately controlled by 


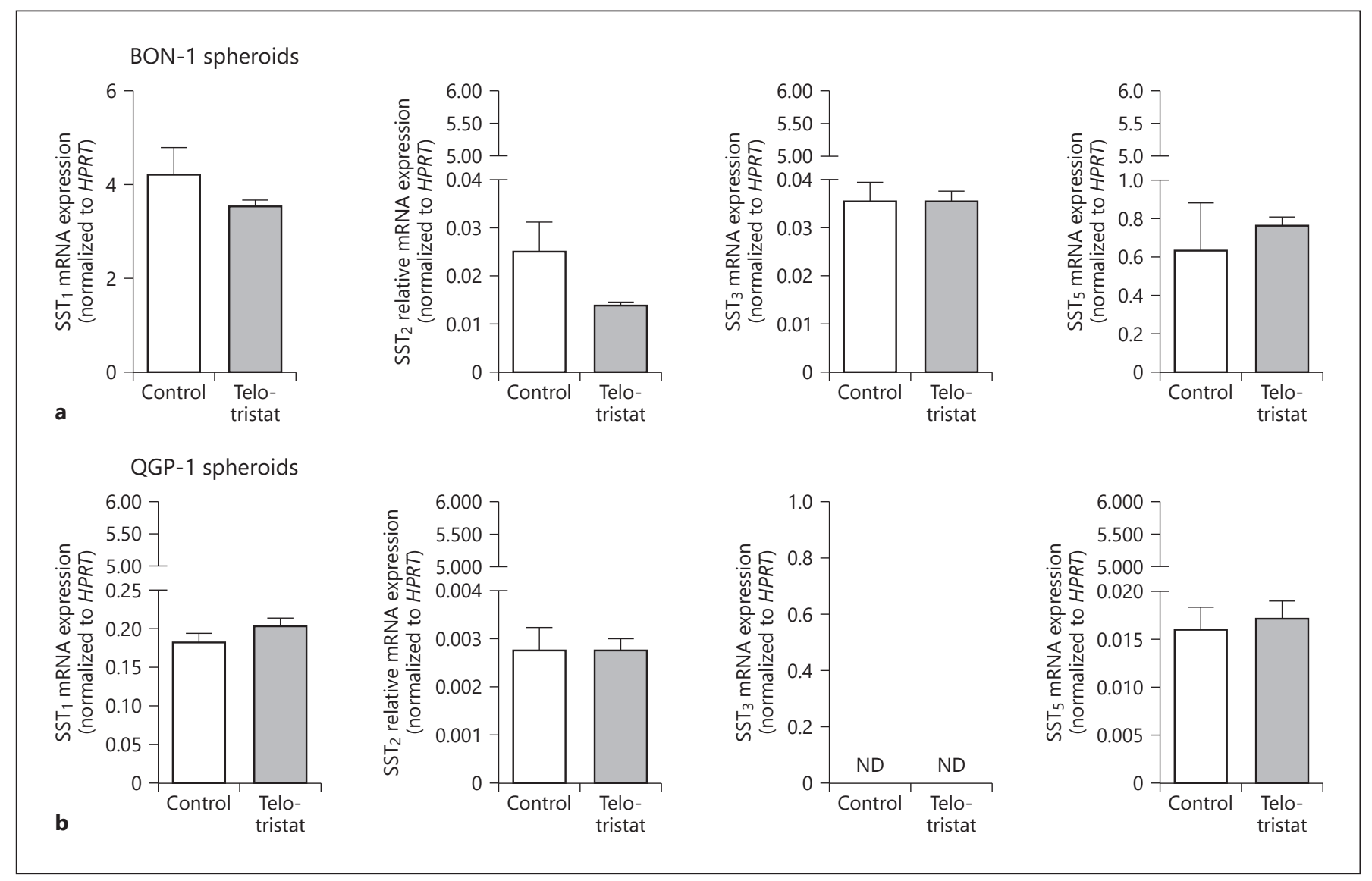

Fig. 5. Effect of telotristat on mRNA expression of somatostatin receptors in BON-1 and QGP-1 cell lines using a 3D spheroid culture system. Relative mRNA expression normalized to HPRT in spheroid cultures of BON-1 (a) and QGP-1 (b) cell lines. The
mRNA expression of BON-1 and QGP-1 spheroids was not statistically significantly altered by telotristat at a concentration of $5 \times$ $10^{-8}$ and $10^{-9} \mathrm{M}$, respectively. Values represent mean \pm SEM. ND, non-detectable.
SSAs [17]. For this reason, we evaluated the effects of combined treatment with telotristat and SSAs. Interestingly, despite the fact that the $\mathrm{SST}_{2}$ targeting SSA OCT slightly decreased serotonin secretion in BON-1 cells, its combination with telotristat was slightly less effective than the effect of telotristat alone. In QGP-1, no statistically significant effect of OCT on the inhibitory effect of telotristat on serotonin secretion was observed. According to the available pharmaceutical information of telotristat ethyl, short-acting OCT may decrease the systemic exposure to telotristat; to this aim, short-acting OCT should be administered 30 min before telotristat [43]. In this context, the underlying mechanism, as well as its relevance in the clinical practice should be further explored, preferably in midgut NET cell lines and primary cultures of human midgut NETs. In BON-1, the multiligand SSA PAS inhibited serotonin secretion more potently compared to OCT, which may be explained by the relative high expression of $\mathrm{SST}_{5}$ in this cell line $[44,45]$. Moreover, this inhibitory effect was increased when PAS was combined with telotristat. Previous studies have evaluated the applicability of PAS in patients with carcinoid tumors resistant to other SSAs; unfortunately, the effects on symptom control are contradictory $[46,47]$. Some studies have reported that in $33 \%$ of patients with carcinoid syndrome, PAS LAR is effective [46], but a randomized phase III study of PAS LAR versus high-dose (40 $\mathrm{mg}$ ) OCT LAR for symptom control in patients with advanced GEP-NETs and carcinoid syndrome, whose disease-related symptoms were uncontrolled by first-generation SSAs at maximum approved doses, showed that PAS LAR was not superior to OCT LAR [47]. The increased incidence of hyperglycemia may limit its use as well [48]. It may therefore be important to evaluate the SSTs expression profile of the tumors using RT-qPCR or immunohistochemistry [49-51] in order to consider alternative therapeutic options in functional NETs. 
Fig. 6. Effect of octreotide, pasireotide, and telotristat on mRNA expression profile of tryptophan hydroxylase (TPH-1) in BON1 and QGP-1 cell lines in monolayer culture. Relative mRNA expression, normalized to HPRT, in monolayer cultures of BON-1 (a) and QGP-1 (b) cell lines. The mRNA expression of TPH-1 in BON-1 and QGP-1 cells was not statistically significantly altered by octreotide $\left(10^{-8} \mathrm{M}\right)$, pasireotide $\left(10^{-8} \mathrm{M}\right)$, or telotristat $\left(5 \times 10^{-8} \mathrm{M}\right.$ for BON-1 and $10^{-9} \mathrm{M}$ for QGP-1). Values represent mean \pm SEM (relative mRNA expression of TPH-1 in control samples for BON-1: $9.6 \pm 1.1$; QGP-1: $7.4 \pm 0.8$ ).
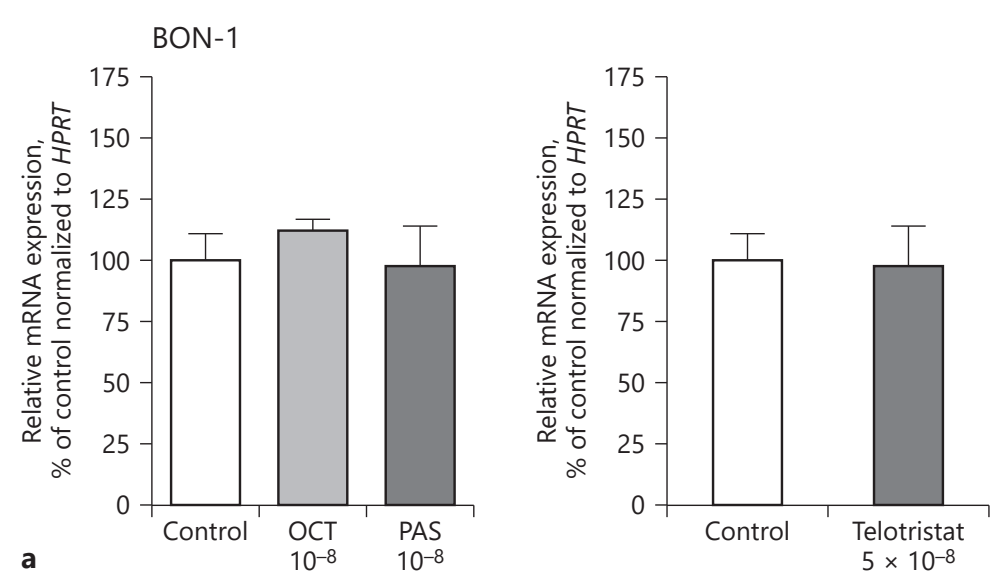

QGP-1
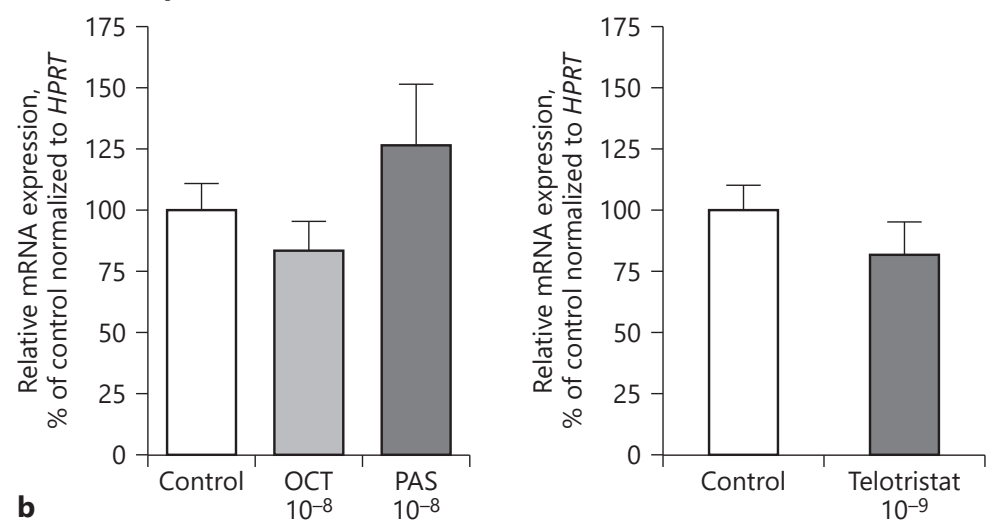

Additionally, it has previously been described that the inhibition of serotonin production may modify the molecular expression of some genes [41]. Since the combination therapy with OCT slightly reduced the effect of telotristat in BON-1 cells, we aimed to evaluate the effect of telotristat on mRNA expression of SSTs in monolayer and spheroids. However, no effect of telotristat on SSTs subtype expression was found. Serotonin biosynthesis is regulated by two isoforms of the enzyme TPH of which TPH-1 is localized predominantly in gastrointestinal enteroendocrine cells and TPH2 in the central nervous system [52]. It is well known that telotristat is a highly specific and potent inhibitor of TPH [14]. In order to further explore the interaction between SSAs and telotristat, we evaluated the effect of SSA on TPH-1 expression. However, OCT and PAS did not alter the expression of TPH-1 at mRNA or protein level. Therefore, the mechanism of interaction between OCT and telotristat remains to be elucidated.

In vitro Efficacy of Telotristat in Neuroendocrine Tumors
Interestingly, BON-1 cells secreted a higher amount of serotonin, compared to QGP-1. Moreover, QGP-1 cells were more sensitive to telotristat than BON-1. Nevertheless, mRNA expression of TPH-1 was comparable between BON-1 and QGP-1 cells, suggesting that other mechanisms should be responsible for the above differences in serotonin secretion between the two NET cell models.

Finally, several autocrine effects of serotonin have been previously described, especially in relation to tumor progression [53]. Specifically, serotonin may promote the proliferation of several tumor cell types [54-56], including lung non-small cell carcinoma, lung atypical carcinoid, as well as small intestine NET cells [57]. This autocrine effect may be reversed through the inhibition of serotonin synthesis, release, and/or receptor activation [57]. To this aim, we evaluated the possible paracrine/autocrine effects of serotonin on cell proliferation in a 3D spheroid NET model. This culture system seems to better reproduce tumor cell 


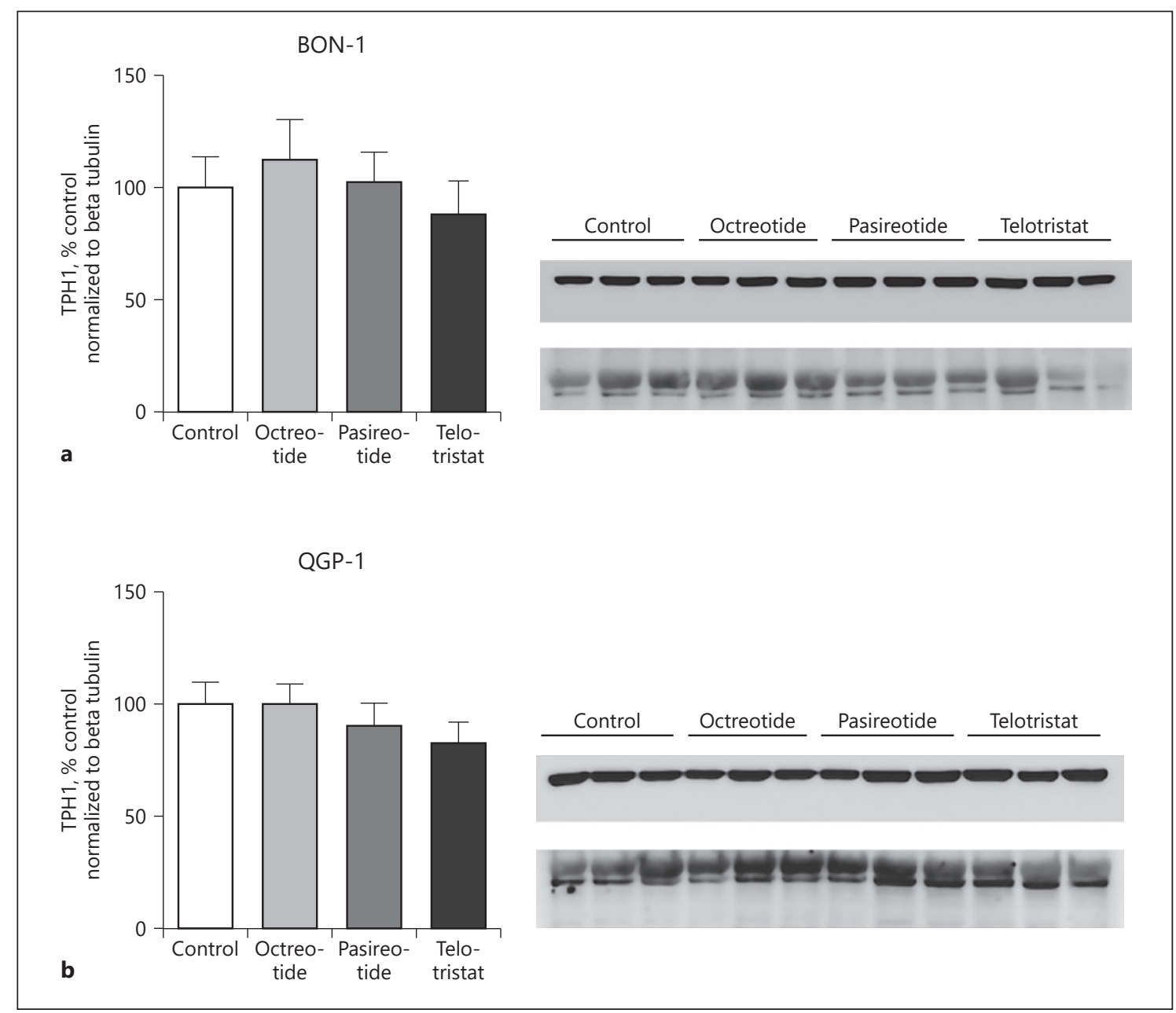

Fig. 7. Effect of octreotide, pasireotide, and telotristat on protein expression profile of TPH-1 in BON-1 (a) and QGP-1 (b) cell lines using Western blotting in monolayer cultures. The protein expression of TPH-1 in BON-1 and QGP-1 cells and $\mathrm{SST}_{2}$ in BON-1 was

microenvironment, since it mimics the in vivo tumor cellcell signaling, growth kinetics, extracellular matrix deposition, nutrients-oxygen conditions, gene expression, drug resistance, cell heterogeneity, and cell-cell physical interactions $[58,59]$. Despite the above earlier observations, we did not observe changes in cell proliferation by treatment with telotristat, even when serotonin production was fully abolished. The discrepancy among the results may be explained by the difference in the origin of the used cell lines, which is also related to the considerable heterogeneity in NETs [60], also to the amount of serotonin secretion per cell line. Further studies including serotonin-producing NET cell lines of different origin (e.g., midgut), co-cultures with other cell lines (e.g., fibroblasts) and in vivo models should be performed. In this sense, the paracrine effect of not statistically significantly altered by octreotide $\left(10^{-8} \mathrm{M}\right)$, pasireotide $\left(10^{-8} \mathrm{M}\right)$, or telotristat $\left(5 \times 10^{-8} \mathrm{M}\right.$ for BON-1 and $10^{-9} \mathrm{M}$ for QGP-1). Values represent mean \pm SEM.

serotonin on the tumor microenvironment may provide additional information for explaining NET pathogenesis and to identify putative additional targets.

Other paracrine effects of serotonin include energy homeostasis and immune cell activation [61-64]. In this context, the inhibition of its production might have additional clinical applications that still need to be elucidated. Despite this, the TPH-1 inhibitor LP533401 did not have beneficial effects in an inflammatory model of periodontal disease [65], suggesting that, as in our study, the paracrine effect of this hormone still needs to be elucidated. Despite the fact that telotristat etiprate is already commercially available for the control of diarrhea in SSAresistant carcinoid syndrome patients, it would be interesting to find out whether different serotonin-producing 
NET models exert a differential sensitivity to the drug. In addition, it is not known whether inhibition of paracrineor autocrine-secreted serotonin by telotristat, without or with SSA, has an impact on NET proliferation. To address this issue, we used the 3D cell culture models of spheroids in this study. Future studies, including co-cultures with other cells, such as fibroblasts or immune cells, may show whether inhibition of serotonin production also has an impact on tumor-stromal interactions.

The lack of previously published articles on the direct in vitro effects of telotristat limits the depth of the discussion of our results. The in vitro effectiveness of telotristat can be evaluated in a small intestinal (SI) NET cell line model, or even primary cultures of midgut NET, which would represent the ideal tumor model, since carcinoid syndrome is more frequently associated with midgut carcinoids $[6,66]$. Midgut NET cell lines are not widely available, and appropriate primary cultures are difficult to establish. A recent study showed that of seven established NET cell lines, only the SI-NET lines GOT-1 and P-STS and the PNET lines BON-1 and QGP-1 displayed a neuroendocrine phenotype and disease-characteristic mutations, while the other supposed SI-NET originating cell lines, e.g. KRJ-I, L-STS, and H-STS, did not and were identified as lymphoblastoid (KRJ-1) [23]. Unfortunately, the GOT-1 and P-STS cell lines are not available in our laboratory to confirm our findings in an SI-NET model. A previous report described the enterochromaffin origin of KRJ-I cells and suggested that due to the differences between this cell line and BON1 cells, both cell lines represent different models of enterochromaffin cell-derived NETs [67]. In this context, further studies evaluating the neuroendocrine characteristics of the available cell lines should be performed in order to improve their selection and use.

To conclude, this study provides for the first time a comprehensive evaluation of the effect of telotristat in an in vitro NET model, confirming the potent inhibitory effect of clinically feasible concentrations of telotristat on serotonin release. We provided evidence for the absence of direct cell toxicity and showed additive inhibitory effects of telotristat and the multiligand SSA PAS on serotonin secretion.

\section{Statement of Ethics}

The authors have no ethical conflicts to disclose.

\section{Disclosure Statement}

There are no conflicts of interest for this research.

\section{References}

1 Schnirer II 2nd, Yao JC, Ajani JA. Carcinoid-a comprehensive review. Acta Oncol. 2003;42(7):672-92.

2 de Herder WW. Tumours of the midgut (jejunum, ileum and ascending colon, including carcinoid syndrome). Best Pract Res Clin Gastroenterol. 2005 Oct;19(5):705-15.

3 Best J, Nijhout HF, Reed M. Serotonin synthesis, release and reuptake in terminals: a mathematical model. Theor Biol Med Model. 2010 Aug;7(1):34.

4 Rorstad O. Prognostic indicators for carcinoid neuroendocrine tumors of the gastrointestinal tract. J Surg Oncol. 2005 Mar;89(3):151-60.

5 Kulke MH, Shah MH, Benson AB 3rd, Bergsland E, Berlin JD, Blaszkowsky LS, et al.; National comprehensive cancer network. Neuroendocrine tumors, version 1.2015. J Natl Compr Canc Netw. 2015 Jan;13(1):78-108.

6 van der Lely AJ, de Herder WW. Carcinoid syndrome: diagnosis and medical management. Arq Bras Endocrinol Metabol. 2005 Oct;49(5):850-60.
7 Zandee WT, Kamp K, van Adrichem RC, Feelders RA, de Herder WW. Limited value for urinary 5-HIAA excretion as prognostic marker in gastrointestinal neuroendocrine tumours. Eur J Endocrinol. 2016 Nov;175(5):361-6.

8 Kulke MH, Hörsch D, Caplin ME, Anthony LB, Bergsland E, Öberg K, et al. Telotristat Ethyl, a Tryptophan Hydroxylase Inhibitor for the Treatment of Carcinoid Syndrome. J Clin Oncol. 2017 Jan;35(1):14-23.

9 O’Toole D, Ducreux M, Bommelaer G, Wemeau JL, Bouché O, Catus F, et al. Treatment of carcinoid syndrome: a prospective crossover evaluation of lanreotide versus octreotide in terms of efficacy, patient acceptability, and tolerance. Cancer. 2000 Feb;88(4):770-6.

10 Ruszniewski P, Ish-Shalom S, Wymenga M, O'Toole D, Arnold R, Tomassetti P, et al. Rapid and sustained relief from the symptoms of carcinoid syndrome: results from an open 6-month study of the 28-day prolonged-release formulation of lanreotide. Neuroendocrinology. 2004;80(4):244-51.

11 Janson ET, Oberg K. Long-term management of the carcinoid syndrome. Treatment with octreotide alone and in combination with alphainterferon. Acta Oncol. 1993;32(2):225-9.
12 Plöckinger U, Wiedenmann B. Neuroendocrine tumors. Biotherapy. Best Pract Res Clin Endocrinol Metab. 2007 Mar;21(1):145-62.

13 Liu Q, Yang Q, Sun W, Vogel P, Heydorn W, $\mathrm{Yu} X \mathrm{Q}$, et al. Discovery and characterization of novel tryptophan hydroxylase inhibitors that selectively inhibit serotonin synthesis in the gastrointestinal tract. J Pharmacol Exp Ther. 2008 Apr;325(1):47-55.

14 Lapuerta P, Zambrowicz B, Fleming D, Wheeler D, Sands A. Telotristat etiprate, a novel inhibitor of serotonin synthesis for the treatment of carcinoid sy ndrome. Clin Investig (Lond). 2015;5(5):447-56.

15 Pavel M, Gross DJ, Benavent M, Perros P, Srirajaskanthan $\mathrm{R}$, Warner $\mathrm{RR}$, et al. Telotristat ethyl in carcinoid syndrome: safety and efficacy in the TELECAST phase 3 trial. Endocr Relat Cancer. 2018 Mar;25(3):309-22.

16 European Medicine Agencies Approves Xermelo. EMA/471777/2017.EMEA/H/C/003937. Available at: https://www.ema.europa.eu/en/ medicines/human/EPAR/xermelo.
In vitro Efficacy of Telotristat in Neuroendocrine Tumors
Neuroendocrinology 2020;110:351-363 DOI: $10.1159 / 000502200$ 
17 FDA News Release. FDA Approves Xermelo for Carcinoid Syndrome Diarrhea. Silver Springs: FDA; 2017. Available at: https:// www.fda.gov/newsevents/newsroom/pressannouncements/ucm544035.htm

18 National Comprehensive Cancer Network. Neuroendocrine tumors (version 3.2017). Fort Washington: NCCN; 2017. Available at: https://www.nccn.org/professionals/physician_gls/pdf/neuroendocrine.pdf

19 Kaku M, Nishiyama T, Yagawa K, Abe M. Establishment of a carcinoembryonic antigenproducing cell line from human pancreatic carcinoma. Gan. 1980 Oct;71(5):596-601.

20 La Rosa S, Franzi F, Albarello L, Schmitt A, Bernasconi B, Tibiletti MG, et al. Serotoninproducing enterochromaffin cell tumors of the pancreas: clinicopathologic study of 15 cases and comparison with intestinal enterochromaffin cell tumors. Pancreas. 2011 Aug; 40(6):883-95.

21 Walter T, Hervieu V, Adham M, Gincul R, Poncet G, Pilleul F, et al. Primary neuroendocrine tumors of the main pancreatic duct: a rare entity. Virchows Arch. 2011 May;458(5): 537-46.

22 Tsoukalas N, Chatzellis E, Rontogianni D, Alexandraki KI, Boutzios G, Angelousi A, et al. Pancreatic carcinoids (serotonin-producing pancreatic neuroendocrine neoplasms): report of 5 cases and review of the literature. Medicine(Baltimore).2017 Apr;96(16):e6201.

23 Hofving T, Arvidsson Y, Almobarak B, Inge $\mathrm{L}$, Pfragner R, Persson M, et al. The neuroendocrine phenotype, genomic profile and therapeutic sensitivity of GEPNET cell lines. Endocr Relat Cancer. 2018 Mar;25(3):367-80.

24 Tran VS, Marion-Audibert AM, Karatekin E, Huet S, Cribier S, Guillaumie K, et al. Serotonin secretion by human carcinoid BON cells. Ann N Y Acad Sci. 2004 Apr;1014(1):179-88.

25 Doihara H, Nozawa K, Kojima R, KawabataShoda E, Yokoyama T, Ito H. QGP-1 cells release 5-HT via TRPA1 activation; a model of human enterochromaffin cells. Mol Cell Biochem. 2009 Nov;331(1-2):239-45.

26 Chen X, Shen G, Jiang J, Liu H, Hu K, Darstein $\mathrm{C}$, et al. Pharmacokinetics and safety of subcutaneous pasireotide and intramuscular pasireotide long-acting release in Chinese male healthy volunteers: a phase I, single-center, open-label, randomized study. Clin Ther. 2014 Aug;36(8):1196-210.

27 Mohamed A, Blanchard MP, Albertelli M, Barbieri F, Brue T, Niccoli P, et al. Pasireotide and octreotide antiproliferative effects and sst 2 trafficking in human pancreatic neuroendocrine tumor cultures. Endocr Relat Cancer. 2014 Oct;21(5):691-704.

28 Markham A. Telotristat Ethyl: First Global Approval. Drugs. 2017 May;77(7):793-8.

29 Wängberg B, Nilsson O, Wigander A, Johansson V, Forssell-Aronsson E, Andersson P, et al. [Somatostatin receptors. A new way to diagnosis and therapy of neuroendocrine tumors]. Lakartidningen. 1997 Mar;94(10):829-30.
30 Hofland LJ, van Koetsveld PM, Lamberts SW. Percoll density gradient centrifugation of rat pituitary tumor cells: a study of functional heterogeneity within and between tumors with respect to growth rates, prolactin production and responsiveness to the somatostatin analog SMS 201-995. Eur J Cancer. 1990 Jan;26(1):37-44.

31 Downs TR, Wilfinger WW. Fluorometric quantification of DNA in cells and tissue. Anal Biochem. 1983 Jun;131(2):538-47.

32 O'Brien MC, Bolton WE. Comparison of cell viability probes compatible with fixation and permeabilization for combined surface and intracellular staining in flow cytometry. Cytometry. 1995 Mar;19(3):243-55.

33 Ferone D, Pivonello R, Van Hagen PM, Dalm VA, Lichtenauer-Kaligis EG, Waaijers M, et al. Quantitative and functional expression of somatostatin receptor subtypes in human thymocytes. Am J Physiol Endocrinol Metab. 2002 Nov;283(5):E1056-66.

34 Rasmussen R. Quantification on the LightCycler. In: Meters S, Wittwer C, Nakagawara K, editors. Rapid cycle real-time PCR. Methods and applications. Heidelberg: Springer; 2001. p. 21-34.

35 Schmittgen TD, Livak KJ. Analyzing realtime PCR data by the comparative $\mathrm{C}(\mathrm{T})$ method. Nat Protoc. 2008;3(6):1101-8.

36 Pfaffl MW. A new mathematical model for relative quantification in real-time RT-PCR. Nucleic Acids Res. 2001 May;29(9):e45.

37 Kulke MH, O'Dorisio T, Phan A, Bergsland E, Law L, Banks P, et al. Telotristat etiprate, a novel serotonin synthesis inhibitor, in patients with carcinoid syndrome and diarrhea not adequately controlled by octreotide. Endocr Relat Cancer. 2014 Oct;21(5):705-14.

38 Pavel M, Hörsch D, Caplin M, Ramage J, Seufferlein T, Valle J, et al. Telotristat etiprate for carcinoid syndrome: a single-arm, multicenter trial. J Clin Endocrinol Metab. 2015 Apr;100(4):1511-9.

39 Welford RW, Vercauteren M, Trébaul A, Cattaneo C, Eckert D, Garzotti M, et al. Serotonin biosynthesis as a predictive marker of serotonin pharmacodynamics and disease-induced dysregulation. Sci Rep. 2016 Jul;6(1): 30059.

40 Margolis KG, Stevanovic K, Li Z, Yang QM, Oravecz T, Zambrowicz B, et al. Pharmacological reduction of mucosal but not neuronal serotonin opposes inflammation in mouse intestine. Gut. 2014 Jun;63(6):928-37.

41 Kim JJ, Wang H, Terc JD, Zambrowicz B, Yang QM, Khan WI. Blocking peripheral serotonin synthesis by telotristat etiprate (LX1032/LX1606) reduces severity of both chemical- and infection-induced intestinal inflammation. Am J Physiol Gastrointest Liver Physiol. 2015 Sep;309(6):G455-65.
42 Pawlak D, Znorko B, Kalaska B, Domaniewski T, Zawadzki R, Lipowicz P, et al. LP533401 restores bone health in 5/6 nephrectomized rats by a decrease of gut-derived serotonin and regulation of serum phosphate through the inhibition of phosphate co-transporters expression in the kidneys. Bone. 2018 Aug; 113:124-36.

43 FDA. Full prescribing information: Xermelo. 2017. Available at: https://www.accessdata. fda.gov/drugsatfda_docs/label/2017/ 208794s000lbl.pdf

44 Herrera-Martínez AD. F.R., Castaño JP, Van Dungen R, Dogan-Oruc F, Van Koetsveld P, Hofland LJ, Potential Effects of Ketoconazole on ACTHProducing and Non-ACTH-Producing Neuroendocrine Tumors. ENETS Conference, Abstract C06. Barcelona., 2018.

45 Veenstra MJ, van Koetsveld PM, Dogan F, Farrell WE, Feelders RA, Lamberts SW, et al. Epidrug-induced upregulation of functional somatostatin type 2 receptors in human pancreatic neuroendocrine tumor cells. Oncotarget. 2016 May;9(19):14791-802.

46 Kvols LK, Oberg KE, O’Dorisio TM, Mohideen P, de Herder WW, Arnold R, et al. Pasireotide (SOM230) shows efficacy and tolerability in the treatment of patients with advanced neuroendocrine tumors refractory or resistant to octreotide LAR: results from a phase II study. Endocr Relat Cancer. 2012 Sep;19(5):657-66.

47 Wolin EM, Jarzab B, Eriksson B, Walter T, Toumpanakis C, Morse MA, et al. Phase III study of pasireotide long-acting release in patients with metastatic neuroendocrine tumors and carcinoid symptoms refractory to available somatostatin analogues. Drug Des Devel Ther. 2015 Sep;9:5075-86.

48 Cives M, Kunz PL, Morse B, Coppola D, Schell MJ, Campos T, et al. Phase II clinical trial of pasireotide long-acting repeatable in patients with metastatic neuroendocrine tumors. Endocr Relat Cancer. 2015 Feb;22(1): $1-9$

49 de Herder WW, Hofland LJ, van der Lely AJ, Lamberts SW. Somatostatin receptors in gastroentero-pancreatic neuroendocrine tumours. Endocr Relat Cancer. 2003 Dec;10(4): 451-8.

50 Kanakis G, Grimelius L, Spathis A, Tringidou R, Rassidakis GZ, Öberg K, et al. Expression of Somatostatin Receptors 1-5 and Dopamine Receptor 2 in Lung Carcinoids: Implications for a Therapeutic Role. Neuroendocrinology. 2015;101(3):211-22.

51 Herrera-Martínez AD, Gahete MD, PedrazaArevalo S, Sánchez-Sánchez R, Ortega-Salas $\mathrm{R}$, Serrano-Blanch R, et al. Clinical and functional implication of the components of somatostatin system in gastroenteropancreatic neuroendocrine tumors. Endocrine. 2018 Feb;59(2):426-37.

52 Swami T, Weber HC. Updates on the biology of serotonin and tryptophan hydroxylase. Curr Opin Endocrinol Diabetes Obes. 2018 Feb;25(1):12-21. 
53 Sarrouilhe D, Clarhaut J, Defamie N, Mesnil M. Serotonin and cancer: what is the link? Curr Mol Med. 2015;15(1):62-77.

54 Koba S, Pakala R, Watanabe T, Katagiri T, Benedict CR. Vascular smooth muscle proliferation: synergistic interaction between serotonin and low density lipoproteins. J Am Coll Cardiol. 1999 Nov;34(5):1644-51.

55 Banasr M, Hery M, Printemps R, Daszuta A. Serotonin-induced increases in adult cell proliferation and neurogenesis are mediated through different and common 5-HT receptor subtypes in the dentate gyrus and the subventricular zone. Neuropsychopharmacology. 2004 Mar;29(3):450-60.

56 Liang C, Chen W, Zhi X, Ma T, Xia X, Liu H, et al. Serotonin promotes the proliferation of serum-deprived hepatocellular carcinoma cells via upregulation of FOXO3a. Mol Cancer. 2013 Feb;12(1):14.
57 Drozdov I, Kidd M, Gustafsson BI, Svejda B, Joseph R, Pfragner R, et al. Autoregulatory effects of serotonin on proliferation and signaling pathways in lung and small intestine neuroendocrine tumor cell lines. Cancer. 2009 Nov;115(21):4934-45.

58 Edmondson R, Broglie JJ, Adcock AF, Yang L. Three-dimensional cell culture systems and their applications in drug discovery and cellbased biosensors. Assay Drug Dev Technol. 2014 May;12(4):207-18.

59 Costa EC, Moreira AF, de Melo-Diogo D, Gaspar VM, Carvalho MP, Correia IJ. 3D tumor spheroids: an overview on the tools and techniques used for their analysis. Biotechnol Adv. 2016 Dec;34(8):1427-41.

60 Cives M, Soares HP, Strosberg J. Will clinical heterogeneity of neuroendocrine tumors impact their management in the future? Lessons from recent trials. Curr Opin Oncol. 2016 Jul; 28(4):359-66.

61 Spohn SN, Mawe GM. Non-conventional features of peripheral serotonin signalling - the gut and beyond. Nat Rev Gastroenterol Hepatol. 2017 Jul;14(7):412-20.
62 Namkung J, Kim H, Park S. Peripheral Serotonin: a New Player in Systemic Energy Homeostasis. Mol Cells. 2015 Dec;38(12):1023-8.

63 Martin AM, Young RL, Leong L, Rogers GB, Spencer NJ, Jessup CF, et al. The Diverse Metabolic Roles of Peripheral Serotonin. Endocrinology. 2017 May;158(5):1049-63.

64 Herr N, Bode C, Duerschmied D. The Effects of Serotonin in Immune Cells. Front Cardiovasc Med. 2017 Jul;4:48.

65 Lima GM, Corazza BJ, Moraes RM, de Oliveira FE, de Oliveira LD, Franco GC, et al. The effect of an inhibitor of gut serotonin (LP533401) during the induction of periodontal disease. J Periodontal Res. 2016 Oct;51(5):661-8.

66 van der Horst-Schrivers AN, Wymenga AN, Links TP, Willemse PH, Kema IP, de Vries EG. Complications of midgut carcinoid tumors and carcinoid syndrome. Neuroendocrinology. 2004;80 Suppl 1:28-32.

67 Siddique ZL, Drozdov I, Floch J, Gustafsson BI, Stunes K, Pfragner R, et al. KRJ-I and BON cell lines: defining an appropriate enterochromaffin cell neuroendocrine tumor model. Neuroendocrinology. 2009;89(4):458-70. 